\title{
Pengaruh Kepemilikan Manajerial, Kepemilikan Institusional, Profitabilitas, Likuiditas dan Ukuran Perusahaan Terhadap Kebijakan Hutang pada Perusahaan Manufaktur yang Terdaftar Di Bursa Efek Indonesia
}

\author{
Ninta Katharina \\ Universitas Prima Indonesia \\ nintakatharina@unprimdn.ac.id \\ Desri Foryani Saragih \\ Universitas Prima Indonesia \\ desriforyani@gmail.com \\ Cristine Ester Manurung \\ Universitas Prima Indonesia \\ cristineester02@gmail.com

\section{Rosmegawati} \\ Universitas Prima Indonesia \\ megasitumorang208@gmail.com
}

\begin{abstract}
Abstrak
Penelitian ini dilakukan pada industri manufaktur dimana diketahui jika perusahaan manufaktur lebih banyak pakai hutang untuk mendanai kegiatan produksinya misalnya pembelian mesin produksi dan pembelian bahan baku sedangkan jika perusahaan tidak hati-hati dalam mengelola hutangnya perusahaan manufaktur dapat terancam pailit dan kepemilikan saham manajerial akan bergeser menjadi kepemilikan instistusional. Tujuan diadakannya riset ini yaitu untuk mengetahui dan menganalisis apakah secara individual dan simultan variabel independen mempengaruhi kebijakan hutang. Penelitian ini merupakan penelitian deskriptif kuantitatif. Teknik pengumpulan data menggunakan studi dokumentasi yaitu data sekunder dalam bentuk laporan keuangan tahun 2017 2019. Jumlah populasi pada penelitian ini ada 169 perusahaan manufaktur dan perusahaan yang memenuhi kriteria ada sebanyak 38 perusahaan. Teknik analisis data yang digunakan adalah analisis regresi berganda dengan SPSS versi 21. Hasil penelitian ini menunjukkan secara parsial likuiditas berpengaruh terhadap kebijakan hutang sedangkan kepemilikan makajerial, kepemilikan institusional, profitabilitas dan ukuran perusahaan tidak berpengaruh terhadap kebijakan hutangnya. Secara simultan kelima variabel tersebut mempengaruhi signifikan kebijakan hutang. Hasil uji koefisien determinasi pada nilai Adjusted R Square menunjukkan angka 0,647 yang artinya sebesar 64,7\% variasi dari kebijakan hutang yang dapat dijelaskan oleh variabel independen sisanya 35,3\% dipengaruh oleh faktor lain misalnya risiko bisnis, free cash flow dan struktur
\end{abstract}


aktiva. Kesimpulannya hanya likuiditas yang berpengaruh terhadap kebijakan hutang.

Kata Kunci Kepemilikan Manajerial dan Institusional, Profitabilitas, Likuiditas, Ukuran Perusahaan serta Kebijakan Hutang.

\section{PENDAHULUAN}

Para pemegang saham memberikan kepercayaan kepada manajer untuk mengelola, menjalankan perusahaan dan mengatasi berbagai halangan agar dapat tercapai tujuan perusahaan. Dalam pengelolaan perusahaannya manajer memerlukan dana untuk membiayai kegiatan operasional. Salah satu cara untuk mendapatkan dana yaitu dengan cara meningkatkan hutangnya. Suatu perusahaan akan memiliki risiko apabila memiliki komposisi hutang yang besar dalam kebijakan hutangnya, tetapi jika perusahaan tidak memiliki hutang maka perusahaan di nilai tidak bisa menggunakan tambahan modal luar yang dapat meninggikan kegiatan operasional perusahaan. Seperti diketahui pentingnya penggunaan hutang yang hati-hati dapat dilihat pada beberapa perusahaan di Indonesia yang hampir mengalami kebangkrutan akibat kegagalan dalam menggunakan hutangnya. Contohnya pada PT. Tiga Pilar Sejahtera Food, Tbk yang sudah dua kali telat melakukan pembayaran utang bunga dan akhirnya mengeluarkan obligasi sebesar 600 milyar dan Sukuk Ijarah sebesar 300 milyar sehingga akhirnya PT. Tiga Pilar Sejahtera Food, Tbk bebas dari kepailitan. Contoh lainnya pada perusahaan Sariwangi yang memiliki hutang sebanyak 309,6 milyar pada Bank ICBC Indonesia dan tidak sanggup membayar cicilan hutangnya. Perusahaan yang sudah lama berdiri juga yaitu Nyonya Meneer yang terlilit hutang sebanyak 267 milyar yang akhirnya bangkrut karena tidak sanggup membayar hutangnya kepada sejumlah kreditur. Adanya kepemilikan manajerial dan institusional dapat mempengaruhi penggunaan kebijakan hutang karena pemilik saham akan menggunakan alternatif lain terlebih dahulu sebelum menambah hutang. Makin besar profit yang dimiliki organisasi maka akan makin rendah penggunaan hutangnya karena perusahaan bisa memanfaatkan dana internal yang diambil dari retained earning terlebih dahulu. Jika perusahaan memiliki tingkat likuiditas dan ukuran aset yang tinggi, akan lebih gampang untuk mendapatkan kepercayaan dari pihak luar sehingga lebih mudah mendapatkan pendanaan. Penelitian ini dilakukan pada industri manufaktur dimana diketahui jika perusahaan manufaktur lebih banyak pakai hutang untuk mendanai kegiatan produksinya misalnya pembelian mesin produksi dan pembelian bahan baku sedangkan jika perusahaan tidak hatihati dalam mengelola hutangnya perusahaan manufaktur dapat terancam pailit dan kepemilikan saham manajerial akan bergeser menjadi kepemilikan institusional.

\section{LANDASAN TEORI}

\subsection{Kebijakan Hutang}

Menurut Darmayanti, dkk (2018:5) keputusan kebijakan tentang hutang adalah kebijakan yang ditempuh oleh organisasi dalam rangka membiayai kegiatan operasionalnya apabila memanfaatkan hutang biasanya disebut juga dengan financial leverage. 


\subsection{Kebijakan Hutang dan Kepemilikan Manajerial}

Menurut Murwani dan Christiana (2018) kepemilikan yang dimiliki oleh manajerial sebagai pihak manajemen perusahaan bisa merasakan langsung dampak dari kebijakan yang sudah diambil terutama tentang keputusan tingkat hutang yang akan digunakan. Dengan demikian, biasanya manajer akan lebih was-was dalam pengambilan kebijakan mengenai hutangnya.

\subsection{Kebijakan Hutang dan Kepemilikan Institusional}

Menurut Lestari (2019:3) makin besarnya kepemilikan institusional menunjukkan makin efisiennya pemanfaatan aset perusahaannya. Hal ini dikarenakan kepemilikan institusional berperan sebagai upaya dini dalam mencegah pemborosan yang dilakukan manajemen.

\subsection{Kebijakan Hutang dan Profitabilitas}

Menurut Sinaga (2014:353) makin tingginya keuntungan yang diperoleh perusahaan artinya makin rendahnya utang.

Menurut Kamaludin dan Indriani (2012:326) suatu organisasi yang memiliki profit yang tinggi sudah tentu akan mempunyai retained earning yang tinggi juga, sehingga $\mathrm{n}$ perusahaan cenderung menyukai untuk memakai reatained earningnya terlebih dahulu sebelum memilih hutang sebagai pendanaan investasinya.

\subsection{Kebijakan Hutang dan Likuiditas}

Menurut Sunyoto (2018:14) jika perusahaan tersebut likuiditasnya tidak mencukupi maka perusahaan bisa mengajukan pinjaman pada bank melalui pinjaman jangka pendek, cerukan dan anjak piutang.

Menurut Kasmir (2015:129) adanya kelalaian manajemen dalam menjalankan usaha dapat disebabkan karena ketidakmampuan perusahaan dalam membayar hutangnya. Kelalaian lainnya dapat disebabkan karena manajer perusahaan tidak menganalisis rasio keuangan secara berkala sehingga perusahaan tidak mengetahui kondisi yang sebenarnya jika perusahaan sudah dalam keadaan yang tidak mampu membayar hutangnya. Jika perusahaan melakukan analisis rasio likuiditas dari awal maka perusahaan dapat mencari jalan keluar yang berkaitan dengan ketidakmampuan perusahaan untuk membayar hutang lancarnya.

\subsection{Pengaruh Ukuran Perusahaan terhadap Kebijakan Hutang}

Menurut Mulyawan (2015:247) ukuran suatu perusahaan menunjukkan bahwa makin besarnya suatu organisasi, makin besar juga hutangnya. Perusahaan yang kecil dan masih baru berkemungkinan mempunyai arus kas yang kecil untuk memiliki peluang dari investasi yang untung, juga tidak memiliki akses untuk memasuki pasar modal reguler sehingga tidak dapat mengajak pihak luar sebagai rekan kerjanya.

Menurut Sitangang (2013: 76) Size perusahaan dengan kapitalisasi pasar atau penjualan yang besar menujukkan prestasi perusahaan. Perusahaan yang besar akan lebih mudah mendapatkan akses ke sumber dana untuk memperoleh tambahan modal dengan utang.

Menurut Sinaga (2014:352), perusahaan besar cenderung akan melalukan diversifikasi usaha lebih banyak dari pada perusahaan kecil. Oleh karena itu kemungkinan kegagalan dalam menjalankan usaha atau kebangkrutan akan lebih kecil. Ukuran perusahaan sering di jadikan 
indikator bagi kemungkinan terjadinya kebangkrutan bagi suatu perusahaan, dimana perusahaan dalam ukuran lebih besar di pandang lebih mampu menghadapi krisis dalam menjalankan usahanya.

\subsection{Bagan Hubungan}

Kerangka yang menunjukkan adanya hubungan dapat digambar seperti :

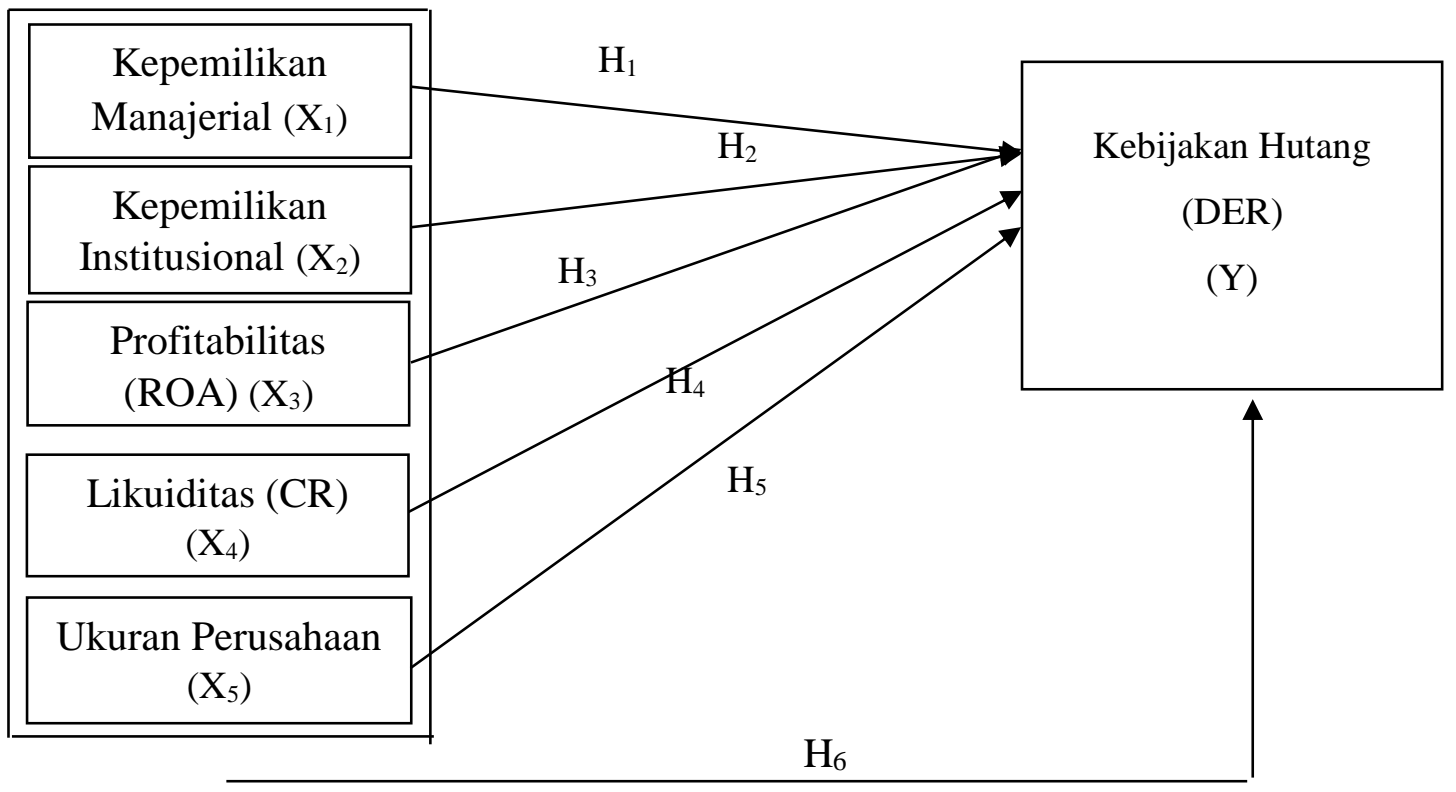

Gambar 1 Kerangka Konseptual

\subsection{Hipotesis Penelitian}

Berdasarkan teori yang telah dipaparkan dari beberapa para ahli maka peneliti akan membuat hipotesis ini sebagai berikut :

$\mathrm{H}_{1} \quad$ : Kepemilikan manajerial secara parsial mempengaruhi kebijakan hutangnya tahun 20172019.

$\mathrm{H}_{2}$ : Kepemilikan institusional mempengaruhi secara parsial kebijakan hutangnya tahun 20172019.

$\mathrm{H}_{3}$ : Profitabilitas (ROA) mempengaruhi secara parsial kebijakan hutangnya tahun 20172019.

$\mathrm{H}_{4}$ : Likuiditas (CR) mempengaruhi secara parsial kebijakan hutangnya tahun 2017-2019.

$\mathrm{H}_{5}$ : Ukuran perusahaan berpengaruh secara parsial terhadap kebijakan hutangnya tahun 20172019.

$\mathrm{H}_{6}$ : kepemilikan manajerial, kepemilikan institusional, profitabilitas (ROA), likuiditas (CR) dan ukuran perusahaan secara simultan mempengaruhi kebijakan hutangnya tahun 20172019. 


\section{METODE PENELITIAN}

\subsection{Lokasi dan Waktu Penelitian}

Objek penelitian ini padaperusahaan manufakturtercatat di Bursa Efek melalui website www.idx.co.id. Penelitian diadakan dari Maret 2020 sampai dengan Juni 2020.

\subsection{Metode Penelitian}

Adapun pendekatan penelitian yang digunakan adalah deduktif, jenis penelitian kuantitatif dan bersifat deskriptif.

\subsection{Populasi dan Sampela}

Adapun seluruhperusahaan manufaktur yang tercatat di Bursa Efek sejak tahun 2017hingga tahun 2019 berpopulasi sebanyak169 perusahaan.

Teknik penentuan sampel dalam penelitian ini adalah berdasarkan purposive sampling yaitu pertimbangan yang ditetapkan oleh peneliti. Adapun kriteria pemilihan sampel ini adalah sebagai berikut:

1. Manufaktur yang listed di BEI.

2. Manufaktur yang mempublikasikan laporan keuangan secara lengkap tahun 2017-2019

3. Manufaktur yang memperoleh laba bersih selama tahun 2017-2019 berturut-turut.

4. Manufaktur yang memiliki saham kepemilikan manajerial tahun 2017-2019

Tabel 1. Tabel Pemilihan Sampel

\begin{tabular}{|c|l|c|}
\hline No & \multicolumn{1}{|c|}{ Keterangan } & Jumlah \\
\hline 1. & Perusahaan manufaktur yang listed di BEI & 169 \\
\hline 2. & $\begin{array}{l}\text { Manufaktur yang tidak mempublikasikan data laporannya secara lengkaptahun } \\
2017-2019\end{array}$ & -33 \\
\hline 3. & Manufaktur yang rugidi tahun 2017 -2019 & -51 \\
\hline 4. & $\begin{array}{l}\text { Manufaktur yang tidak memiliki saham kepemilikan manajerial tahun 2017- } \\
2019\end{array}$ & -47 \\
\hline & Jumlah sampel & $\mathbf{3 8}$ \\
\hline & Jumlah periode & $\mathbf{3}$ \\
\hline
\end{tabular}

Total jumlah observasi data dalam penelitian ini yaitu 114 data observasi.

\subsection{Teknik Pengumpulan Data}

Untuk mengumpulkan data yang diperlukan dalam penelitian ini dilakukan dengan teknik dokumentasiyaitu mengumpulkan sumber data laporan keuangan dan dokumen-dokumen yang berkaitan dengan perusahaan manufaktur yang diunduhdi website resmi BEI sejak tahun 2017 sampai dengan 2019.

\subsection{Jenis dan Sumber Data Penelitiana}

Penelitian ini merupakan data sekunder yang diambil dari situs www.idx.co.id dalam bentuk laporan keuangan perusahaan manufaktur. 


\subsection{Identifikasi dan Definisi Operasional Variabel Penelitiana}

Definisi operasionalisasiadalah penjelasan dari variabel yang diteliti. Untuk lebih jelasnya identifikasi dan definisi operasional variabel pada penelitian ini dapat dilihat pada berikut ini :

Tabel 2. Definisi Operasional dan Pengukuran Variabel

\begin{tabular}{|c|c|c|c|}
\hline Variabel & Konsep & Indikator & Skala \\
\hline $\begin{array}{l}\text { Kepemilikan } \\
\text { Manajerial } \\
\quad\left(\mathrm{X}_{1}\right)\end{array}$ & $\begin{array}{l}\text { Kepemilikan saham oleh manajemen } \\
\text { perusahaan yang diukur dengan persentase } \\
\text { jumlah saham yang dimiliki manajemen. } \\
\text { Sumber : Subagyo, dkk (2017:46) }\end{array}$ & $\begin{array}{l}\text { Kepemilikan manajerial }= \\
\text { Jumlah saham manajerial } \\
\text { Jumlah saham beredar } \\
\text { Sumber : Subagyo, dkk (2017:46) }\end{array}$ & Rasio \\
\hline $\begin{array}{l}\text { Kepemilikan } \\
\text { Institusional } \\
\quad\left(\mathrm{X}_{2}\right)\end{array}$ & $\begin{array}{l}\text { Kepemilikan saham oleh pemerintah, institusi } \\
\text { keuangan, institusi berbadan hukum, institusi } \\
\text { luar negeri, dana perwalian dan institusi lainnya } \\
\text { pada akhir tahun } \\
\text { Sumber : Subagyo, dkk (2017:47) }\end{array}$ & $\begin{array}{l}\text { Kepemilikan institusional }= \\
\text { Jumlah saham institusional } \\
\text { Jumlah saham beredar } \\
\text { Sumber : Subagyo, dkk (2017:47) }\end{array}$ & Rasio \\
\hline $\begin{array}{c}\text { Profitabilitas } \\
\left(\mathrm{X}_{3}\right)\end{array}$ & $\begin{array}{l}\text { Profitabilitas dapat diartikan sebagai rasio yang } \\
\text { menggambarkan kemampuan perusahaan untuk } \\
\text { menghasilkan keuntungan } \\
\text { Sumber : Murhadi (2015:63) }\end{array}$ & $\begin{array}{l}\text { ROA }= \\
\frac{\text { Earning After Taxes }}{\text { Total Assets }} \\
\text { Sumber : Sudana }(2011: 22)\end{array}$ & Rasio \\
\hline $\begin{array}{l}\text { Likuiditas } \\
\left(\mathrm{X}_{4}\right)\end{array}$ & $\begin{array}{l}\text { Rasio yang bertujuan untuk mengetahui } \\
\text { kemampuan perusahaan dalam membayar } \\
\text { kewajiban jangka pendek }\end{array}$ & $\begin{array}{l}\text { CR }= \\
\underline{\text { Aktiva Lancar }} \\
\text { Hutang Lancar } \\
\text { Sumber : Sumarsan }(2013: 45)\end{array}$ & Rasuo \\
\hline $\begin{array}{l}\text { Ukuran } \\
\text { Perusahaan } \\
\quad\left(\mathrm{X}_{5}\right)\end{array}$ & $\begin{array}{l}\text { Untuk melihat ukuran perusahaan, investor } \\
\text { melihat dari besar kecilnya perusahaan } \\
\text { Sumber : Sunyoto (2013:6) }\end{array}$ & $\begin{array}{l}\text { Logaritma Natural Asset } \\
\text { Sumber : Rodoni (2014:193) }\end{array}$ & Rasio \\
\hline $\begin{array}{l}\text { Kebijakan } \\
\text { Hutang } \\
\text { (Y) }\end{array}$ & $\begin{array}{l}\text { Kebijakan hutang adalah kebijakan yang } \\
\text { diambil oleh pihak manajemen dalam rangka } \\
\text { memperoleh sumber pembiayaan bagi } \\
\text { perusahaan sehingga dapat digunakan untuk } \\
\text { membiayai aktivitas operasional perusahaan } \\
\text { Sumber : Tjeleni (2013:30) }\end{array}$ & $\begin{array}{l}\text { DER }= \\
\frac{\text { Total Hutang }}{\text { Ekuitas }} \\
\text { Sumber : Kasmir }(2015: 158)\end{array}$ & Rasio \\
\hline
\end{tabular}

\subsection{Uji Asumsi Klasik}

Asumsi klasik adalah syarat statistik mutlak dilakukan pada regresi berganda. Syarat tersebut apabila telah dipenuhi, maka model regresi linear tersebut dikatakan Best Linear Unbiased Estimation. Adapun uji asumsi klasik pada penelitian ini yaitu :

\section{Uji Normality}

Test Normality diuji untuk melihat apakah nilai residual terdistribusi normal atau tidak. Model regresi yang baik adalah memiliki nilai residual yang terdistribusi normal. Uji normalitas pada penelitian ini menggunakan uji histogram, uji normal P Plot, dan uji Kolmogorov Smirnov. 


\section{Uji Multikolonearitas}

Multi kolinearitas adalah untuk melihat ada atau tidaknya korelasi yang tinggi antara variabel-variabel bebas dalam suatu model regresi linear berganda. Untuk mendeteksi tidak adanya multikolinearitas di dalam model regresi dapat dilihat dari jika nilai tolerance $>0.10$ atau sama dengan nilai VIF $<10$.

\section{Uji Autokorelasi}

Uji auto korelasi adalah untuk melihat apakah terjadi korelasi antara suatu periode $t$ dengan periode sebelumnya $(\mathrm{t}-1)$. Uji autokorelasi pada penelitian ini menggunakan uji run test. Pengambilan keputusan dilakukan dengan melihat nilai Asymp. Sig (2-tailed) uji Run Test. Apabila nilai Asymp. Sig (2-tailed) lebih besar dari tingkat signifikansi 0,05 maka dapat disimpulkan tidak terdapat auto korelasi

\section{Uji Heteroskedasticity}

Heteroskedasticity yaitu untuk melihat apakah terdapat ketidaksamaan varians dari residual satu pengamatan kepengamatan yang lain. Deteksi heteroskedastisitas dapat dilakukan dengan metode scatterplot dengan memplotkan nilai ZPRED (nilaiprediksi) dengan SRESID (nilai residualnya). Selain menggunakan grafik uji heteroskedastisitas pada penelitian ini juga menggunakan uji Glejser dimana jika nilai signifikan hasil perhitungan SPSS lebih besar dari 0,05 maka dapat disimpulkan tidak terjadi heteroskedastisitas.

\subsection{Model Analisis Data Penelitian}

\section{Model Penelitian}

Penelitian ini menggunakan teknik analisis regresi linear berganda. Adapun persamaan yang dipakai adalah :

$$
\mathrm{Y}=\mathrm{a}+\mathrm{b}_{1} \mathrm{X}_{1}+\mathrm{b}_{2} \mathrm{X}_{2}+\mathrm{b}_{3} \mathrm{X}_{3}+\mathrm{b}_{4} \mathrm{X}_{4}+\mathrm{b}_{5} \mathrm{X}_{5}+\mathrm{e}
$$

Keterangan:

\begin{tabular}{|c|c|}
\hline $\mathrm{Y}$ & $=$ Kebijakan Hutang \\
\hline $\mathrm{a}$ & $=$ Konstanta \\
\hline$X_{1}$ & $=$ Kepemilikan Manajerial \\
\hline $\mathrm{X}_{2}$ & $=$ Kepemilikan Institusional \\
\hline$X_{3}$ & $=$ Profitabilitas $(\mathrm{ROA})$ \\
\hline $\mathrm{X}_{4}$ & $=$ Likuiditas $(\mathrm{CR})$ \\
\hline $\mathrm{X}_{5}$ & $=$ Ukuran Perusahaan \\
\hline$b_{1, \ldots} . . b_{5}$ & = Koef. variabel \\
\hline & $=$ batas toleransi kesalahan \\
\hline
\end{tabular}

\section{Koefisien Determinasi}

Koefisien determinasi pada penelitian ini untuk mengetahui seberapa besar kemampuan semua variabel bebas dalam menjelaskan varians dari variabel terikatnya. Pada penelitian ini koefisien determinasi dilihat pada nilai Adjusted $R$ Square. 


\section{Uji t}

Uji t untuk menguji bagaimana pengaruh masing-masing variabel bebasnya secara parsial terhadap variabel terikatnya. Uji ini dapat dilakukan dengan mambandingkan $t$ hitung dengan $t$ tabel atau dengan melihat nilai signifikansi pada masing-masing t hitung, Adapun kriteria sebagai pedoman uji t adalah sebagai berikut :

$\mathrm{H}_{0}$ diterima jika $-\mathrm{t}_{\text {tabel }} \leq \mathrm{t}_{\text {hitung }} \leq \mathrm{t}_{\text {tabel }}$ dan signifikan $>0,05$

$\mathrm{H}_{\mathrm{a}}$ diterima jika $-\mathrm{t}_{\text {hitung }}<-\mathrm{t}_{\text {tabel }}$ atau $\mathrm{t}_{\text {hitung }}>\mathrm{t}_{\text {tabel }}$ dan signifikan $<0,05$

\section{Uji F}

Uji $\mathrm{F}$ adalah uji untuk melihat apakah semua variabel bebasnya secara bersama-sama berpengaruh terhadap variabel terikatnya. Uji $\mathrm{F}$ dapat dilakukan dengan membandingkan $\mathrm{F}$ hitung dengan F Tabel dengan kriteria sebagai berikut :

$\mathrm{H}_{0}$ diterima jika $\mathrm{F}_{\text {hitung }}<\mathrm{F}_{\text {tabel }}$ dan signifikan $>0,05$

$\mathrm{H}_{\mathrm{a}}$ diterima jika $\mathrm{F}_{\text {hitung }}>\mathrm{F}_{\text {tabel }}$ dan signifikan $<0,05$

\section{HASIL PENELITIAN}

\subsection{Statistik Deskriptif}

Data pada peneltian ini berjumlah 114 data yaitu 38 perusahaan kali 3 tahun periode penelitian. Berikut ini dapat dilihat gambaran dari data minimum, maksimum, rata-rata dan simpangan baku (standard deviasi) pada masing-masing variabel :

Tabel 4.1. Statistik Deskriptif

\begin{tabular}{|l|r|r|r|r|r|}
\hline \multicolumn{7}{|c|}{ Descriptive Statistics } \\
\hline & $\mathrm{N}$ & Minimum & Maximum & \multicolumn{1}{c|}{ Mean } & \multicolumn{1}{c|}{ Std. Deviation } \\
\hline K.Manajerial & 114 &, 02 & 91,00 & 18,5936 & 24,03632 \\
\hline K.Institusional & 114 & 9,00 & 99,98 & 81,3914 & 24,07014 \\
\hline Profitabilitas & 114 &, 001 &, 227 &, 05642 &, 044506 \\
\hline Likuiditas & 114 &, 726 & 21,705 & 2,87345 & 2,495146 \\
\hline UkuranPerusahaan & 114 & 12,597 & 30,577 & 23,50344 & 5,419530 \\
\hline KebijakanHutang & 114 &, 099 & 3,513 &, 80270 &, 663852 \\
\hline Valid N (listwise) & 114 & & & & \\
\hline
\end{tabular}

Kepemilikan manajerial nilai minimumnya yaitu 0,02\% yang diperoleh PT. Indofood Sukses Makmur, Tbk di tahun 2017-2019 dan nilai maksimumnya yaitu 91\% yang diperoleh PT. Beton Jaya Manunggal, Tbk tahun 2017. Nilai rata-ratanya sebesar 18,5936\%.

Kepemilikan institusional nilai minimumnya yaitu 9\% yang diperoleh PT. Beton Jaya Manunggal, Tbk di tahun 2017 dan nilai maksimumnya yaitu 99,98\% yang diperoleh PT. Indofood Sukses Makmur, Tbk di tahun 2017-2019. Nilai rata-ratanya sebesar 81,3914\%.

Profitabilitas memiliki nilai minimum yaitu 0,001 yang diperoleh PT. Lion Metal Works, Tbk di tahun 2019 dan nilai maksimumnya sebesar 0,227 yang diperoleh PT. Selamat Sempurna, Tbk di tahun 2017. Nilai rata-ratanya sebesar 0,05642.

Likuiditas nilai minimumnya yaitu 0,726 yang diperoleh PT. Pelangi Indah Canindo, Tbk di tahun 2019 dan nilai maksimum sebesar 21,705 yang diperoleh PT. Duta Pertiwi Nusantara, Tbk di tahun 2019. Nilai meannya sebesar 2,87345. 
Ukuran perusahaan nilai minimumnya yaitu 12,597 yang diperoleh PT. Astra Internasional, Tbk di tahun 2017 dan nilai maksimumnya yaitu 30,577 yang diperoleh PT. Mayora Indah, Tbk. Nilai meannya sebesar 23,50344.

Kebijakan hutang nilai minimumnya yaitu 0,099 yang diperoleh PT. Emdeki Utama, Tbk di tahun 2018 dan nilai maksimumnya yaitu 3,513 yang diperoleh PT. Tembaga Mulia Semanan, Tbk di tahun 2017. Nilai rata-ratanya sebesar 0,80270.

\subsection{Uji Asumsi Klasik Uji Normalitas}

Hasil uji pada data awal menunjukkan jika data belum bersitribusi normal karena nilai signifikan $0,003<0,05$ yang dapat dilihat pada tabel berikut :

\begin{tabular}{|c|c|c|}
\hline \multicolumn{3}{|c|}{ One-Sample Kolmogorov-Smirnov Test } \\
\hline & & $\begin{array}{c}\text { Unstandardized } \\
\text { Residual }\end{array}$ \\
\hline \multicolumn{2}{|l|}{$\mathrm{N}$} & 114 \\
\hline \multirow{2}{*}{ Normal Parameters ${ }^{a, b}$} & Mean &, 0000000 \\
\hline & Std. Deviation &, 55699719 \\
\hline \multirow{3}{*}{ Most Extreme Differences } & Absolute &, 171 \\
\hline & Positive &, 171 \\
\hline & Negative &,- 119 \\
\hline \multicolumn{2}{|l|}{ Kolmogorov-Smirnov Z } & 1,825 \\
\hline \multicolumn{2}{|l|}{ Asymp. Sig. (2-tailed) } &, 003 \\
\hline \multicolumn{3}{|c|}{ a. Test distribution is Normal. } \\
\hline \multicolumn{3}{|l|}{ b. Calculated from data. } \\
\hline
\end{tabular}

Dengan demikian data pada penelitian ini kami lakukan pengobatan dengan mentransformasi ke dalam bentuk LN. Adapun hasil uji normalitas setelah transformasi data adalah sebagai berikut:

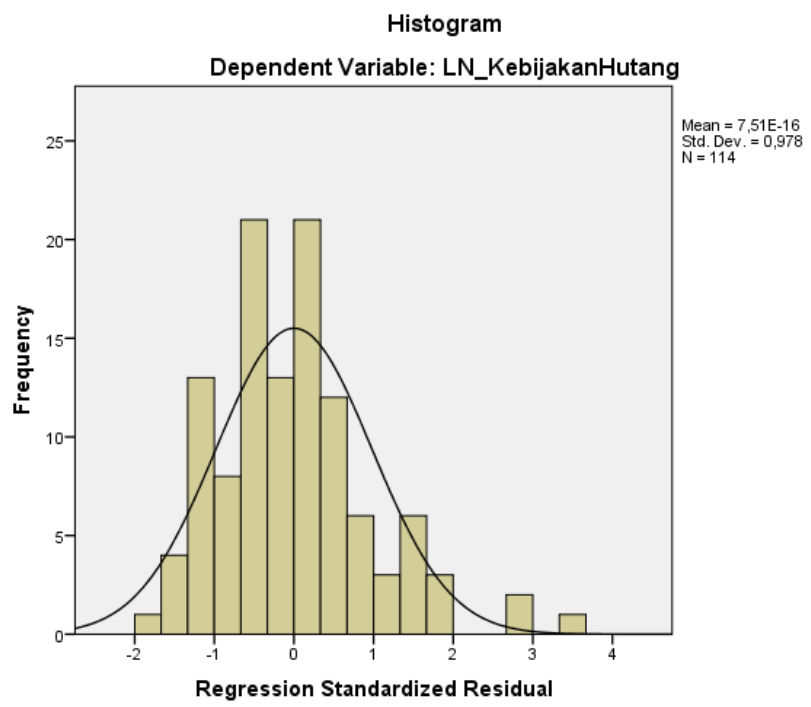

Gambar 4.1. Uji Normalitas Histogram 
Dari gambar 3.1 dapat disimpulkan setelah ditransformasi, data telah berdisribusi normal yang dapat dilihat dari bentuk grafik yang simetris.

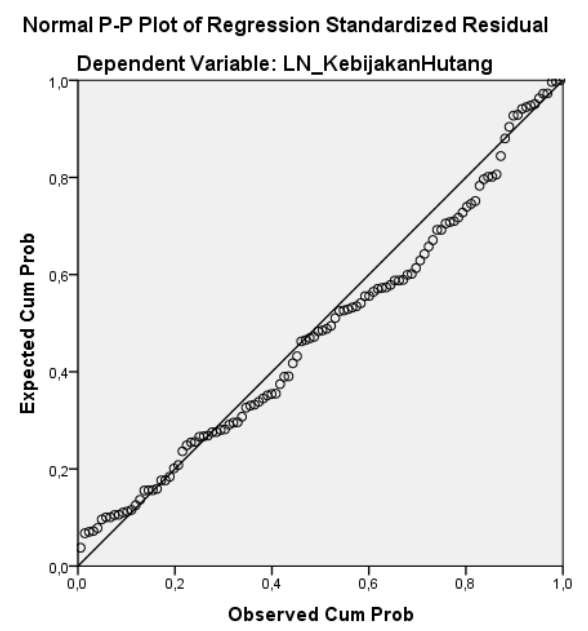

Gambar 4.2. Uji Normalitas P-P Plot

Dari gambar 3.2 dapat dilihat jika data mengikuti diagonalnya sehingga dapat disimpulkan data pada penelitian ini telah berdistribusi normal.

Tabel 4.2. Uji Normalitas Kolmogorov Smirnov One-Sample Kolmogorov-Smirnov Test

\begin{tabular}{|l|l|r|}
\hline \multicolumn{2}{|c|}{ One-Sample Kolmogorov-Smirnov Test } \\
\hline N & $\begin{array}{c}\text { Unstandardized } \\
\text { Residual }\end{array}$ \\
\hline \multirow{2}{*}{ Normal Parameters ${ }^{a, b}$} & Mean &, 114 \\
\cline { 2 - 3 } & Std. Deviation &, 48000000 \\
\hline \multirow{3}{*}{ Most Extreme Differences } & Absolute &, 089 \\
\cline { 2 - 3 } & Positive &, 089 \\
\cline { 2 - 3 } & Negative &,- 054 \\
\hline Kolmogorov-Smirnov Z &, 952 \\
\hline Asymp. Sig. (2-tailed) &, 325 \\
\hline a. Test distribution is Normal. \\
\hline b. Calculated from data. \\
\hline
\end{tabular}

Dari tabel 3.2 dapat dilihat jika nilai signifikan dari hasil uji Kolmogorov Smirnov adalah sebesar 0,325 yang mana nilai ini lebih besar dari 0,05 maka dapat disimpulkan data pada penelitian ini telah berdistribusi normal.

\section{Uji Multikolineritas}

Uji multikolinearitas merupakan uji syarat kedua setelah normalitas. Untuk melihat apakah diantara variabel independen tidak terdapat korelasi maka dapat dilihat nilai tolerance dan VIF. 
Tabel 4.3. Uji Multikolinearitas

\begin{tabular}{|l|l|r|c|}
\hline \multicolumn{3}{|c|}{ Coefficients $^{\mathbf{a}}$} \\
\cline { 3 - 4 } \multicolumn{2}{|c|}{ Model } & \multicolumn{2}{|c|}{ Collinearity Statistics } \\
\cline { 3 - 4 } \multicolumn{1}{|c|}{1} & Tolerance & VIF \\
\hline \multirow{4}{*}{1} & LN_K.Manajerial &, 588 & 1,700 \\
\cline { 2 - 4 } & LN_K.Institusional &, 578 & 1,731 \\
\cline { 2 - 4 } & LN_Profitabilitas &, 918 & 1,089 \\
\cline { 2 - 4 } & LN_Likuiditas &, 949 & 1,088 \\
\cline { 2 - 4 } & LN_UkuranPerusahaan & 1,053 \\
\hline \multicolumn{3}{|l|}{ a. Dependent Variable: LN_KebijakanHutang } \\
\hline
\end{tabular}

Dari hasil uji multikolinearitas menunjukkan data pada penelitian ini tidak terjadi multikolinearitas karena nilai tolerance semua variabel $>0,10$ dan nilai VIF semua variabel $<10$ yang berarti bahwa tidak terdapat korelasi di antara variabel independen yang digunakan.

\section{Uji Autokorelasi}

Pada penelitian time series wajib dilakukan uji autokorelasi. Berikut ini hasil uji autokorelasi menggunakan metode uji Durbin watson:

Tabel 4.4. Uji Autokorelasi

\begin{tabular}{|l|r|r|r|r|r|}
\hline \multicolumn{5}{|c|}{ Model Summary $^{\mathbf{b}}$} \\
\hline Model & $\mathrm{R}$ & $\mathrm{R}$ Square & $\begin{array}{c}\text { Adjusted R } \\
\text { Square }\end{array}$ & $\begin{array}{c}\text { Std. Error of the } \\
\text { Estimate }\end{array}$ & Durbin-Watson \\
\hline 1 &, $814^{\mathrm{a}}$ &, 663 &, 647 &, 49262 & 2,011 \\
\hline $\begin{array}{l}\text { a. Predictors: (Constant), LN_UkuranPerusahaan, LN_K.Manajerial, LN_Profitabilitas, } \\
\text { LN_Likuiditas, LN_K.Institusional }\end{array}$ & & & \\
\hline \multicolumn{2}{|l}{ b. Dependent Variable: LN_KebijakanHutang } \\
\hline
\end{tabular}

Dengan melihat pedoman pada tabel Durbin Watson untuk $\mathrm{k}=5$ dan $\mathrm{n}=114$ maka :
$\mathrm{dL}=1,6042$
$4-\mathrm{dL}=2,3958$
$\mathrm{dU}=1,7869$
$4-\mathrm{dU}=2,2131$

Sehingga hasil uji Durbin Watson memenuhi kriteria kelima yaitu $\mathrm{dU}<\mathrm{d}<4-\mathrm{dU}$ atau $1,7869<2,011<2,2131$ yang artinya tidak ada autokorelasi positif atau negatif pada penelitian ini.

\section{Uji Heteroskedastisitas}

Uji heteroskedastisitas pada penelitian ini menggunakan metode grafik dan statistik, dimana metode statistik yang dipilih menggunakan uji Park. 


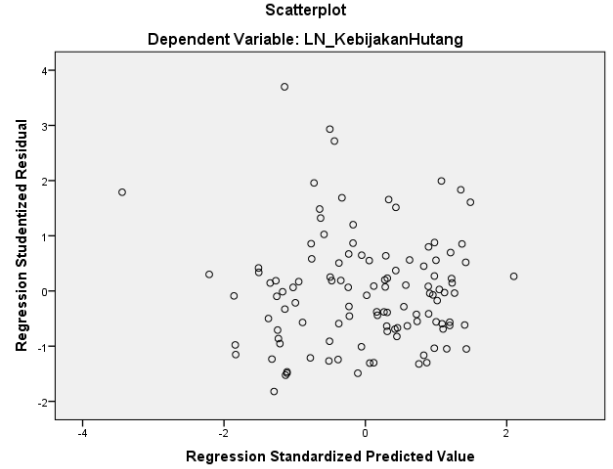

Gambar 4.3. Uji Heteroskedastisitas Scatterplot

Dari hasil uji grafik scatterplot data menunjukkan plot telah tersebar secara acak sehingga data pada penelitian ini telah memenuhi syarat uji asumsi klasik karena tidak terjadi heteroskedastisitas.

Tabel 4.5. Uji Park

\begin{tabular}{|c|c|c|c|c|c|c|}
\hline & & & ficients $^{a}$ & & & \\
\hline & & Unstandardiz & Coefficients & Standardized & $t$ & Sig. \\
\hline & & B & Std. Error & Beta & & \\
\hline & (Constant) &,- 469 & 3,569 & &,- 131 & ,896 \\
\hline & LN_K.Manajerial &,- 106 & ,113 &,- 116 &,- 935 & ,352 \\
\hline 1 & LN_K.Institusional &,- 427 &, 582 &,- 092 &,- 735 & ,464 \\
\hline 1 & LN_Profitabilitas &, 085 & ,245 &, 034 & ,346 &, 730 \\
\hline & LN_Likuiditas & ,378 & ,343 & , 110 & 1,103 & ,272 \\
\hline & LN_UkuranPerusahaan &,- 154 & ,835 &,- 018 &,- 185 & ,854 \\
\hline
\end{tabular}

Dari hasil uji Park, menunjukkan data pada penelitian ini tidak terjadi heteroskedastisitas karena nilai signifikan dari lima variabel independen lebih besar dari batas nilai signifikan yang ditentukan yaitu $>0,05$.

\subsection{Uji Hipotesis}

\section{Analisis Regresi Linear Berganda}

Tabel 4.6. Persamaan Analisis Regresi Linear Berganda

\begin{tabular}{|c|c|c|c|c|}
\hline \multicolumn{5}{|c|}{ Coefficients $^{a}$} \\
\hline \multicolumn{2}{|c|}{ Model } & \multicolumn{2}{|c|}{ Unstandardized Coefficients } & \multirow{2}{*}{$\begin{array}{c}\text { Standardized } \\
\text { Coefficients } \\
\text { Beta }\end{array}$} \\
\hline & & $B$ & Std. Error & \\
\hline \multirow{6}{*}{1} & (Constant) & ,409 & ,791 & \\
\hline & LN_K.Manajerial &,- 042 & ,025 &,- 122 \\
\hline & LN_K.Institusional &,- 091 &, 129 &,- 052 \\
\hline & LN_Profitabilitas &,- 024 & ,054 &,- 025 \\
\hline & LN_Likuiditas & $-1,035$ & ,076 &,- 795 \\
\hline & LN UkuranPerusahaan & ,093 & ,185 &, 029 \\
\hline
\end{tabular}


Dari hasil uji pada tabel 3.6 di atas dapat dibuat persamaan sebagai berikut :

\section{LN_Kebijakan Hutang = 0,409 - 0,042 LN_Kepemilikan Manajerial - 0,091 LN_Kepemilikan Institusional - 0,024 LN_Profitabilitas - 1,035 LN_Likuiditas + 0,093 LN_Ukuran Perusahaan}

Dari persamaan regresi berganda tersebut dapat dijelaskan sebagai berikut :

1. Besarnya nilai konstanta menyatakan bahwa jika variabel independen konstan atau bernilai 0 maka kebijakan hutangbernilai0,409 satuan.

2. Angka -0,042 merupakan besarnya koefisien variabel $\mathrm{X} 1$ yang berarti setiap kenaikan saham manajerialsebesar1 satuan maka akan menurunkan kebijakan hutang sebesar 0,042 satuan.

3. Angka $-0,091$ merupakan besarnya koefisien variabel $\mathrm{X} 2$ yang berarti setiap kenaikan saham institusional sebesar 1 satuan maka akan menurunkan kebijakan hutang sebesar 0,091 satuan.

4. Angka $-0,024$ menunjukkan besarnya koefisien variabel X3 yang berarti setiap kenaikan profitabilitas sebesar 1 satuan maka akan menurunkan kebijakan hutang sebesar 0,024 satuan.

5. Angka $-1,035$ menunjukkan besarnya koefisien variabel $\mathrm{X} 4$ yang berarti setiap kenaikan likuiditas sebesar 1 satuan maka akan menurunkan kebijakan hutang sebesar 1,035 satuan.

6. Angka 0,093 menunjukkan besarnya koefisien variabel X5 yang berarti setiap kenaikan ukuran perusahaan sebesar 1 satuan, meningkatkan kebijakan hutang sebesar 0,093 satuan.

\section{Koefisien Determinasi}

Tabel 4.7. Uji Koefisien Determinasi

\begin{tabular}{|l|c|c|c|c|}
\hline \multicolumn{5}{|c|}{ Model Summary } \\
\hline Model & $\mathrm{R}$ & R Square & $\begin{array}{c}\text { Adjusted R } \\
\text { Square }\end{array}$ & $\begin{array}{c}\text { Std. Error of the } \\
\text { Estimate }\end{array}$ \\
\hline 1 &, $814^{\mathrm{a}}$ &, 663 &, 647 &, 49262 \\
\hline \multicolumn{3}{|c|}{$\begin{array}{l}\text { a. Predictors: (Constant), LN_UkuranPerusahaan, LN_K.Manajerial, } \\
\text { LN_Profitabilitas, LN_Likuiditas, LN_K.Institusional }\end{array}$} \\
\hline
\end{tabular}

Tabel 3.7 hasil uji koefisien determinasi diperoleh nilai Adjusted R Square sebesar 0,647 yang artinya sebesar 64,7\% dari variasi kebijakan hutang dapat dijelaskan oleh kelima variabel independen yang digunakan dimana sisanya sebesar 35,3\% dipengaruhi oleh faktor lainnya seperti risiko bisnis, free cash flow, struktur aktiva dan lainnya.

\section{Uji F}

Tabel 3.8. Uji F

\begin{tabular}{|l|l|r|r|r|r|c|}
\hline \multicolumn{7}{|c|}{ ANOVA $^{\mathrm{a}}$} \\
\hline \multicolumn{1}{|l|}{ Model } & Sum of Squares & df & Mean Square & F & Sig. \\
\hline \multirow{3}{*}{1} & Regression & 51,487 & 5 & 10,297 & 42,433 &, $000^{\mathrm{b}}$ \\
\cline { 2 - 7 } & Residual & 26,209 & 108 &, 243 & & \\
\cline { 2 - 7 } & Total & 77,696 & 113 & & & \\
\hline \multicolumn{2}{|l|}{ a. Dependent Variable: LN_KebijakanHutang } \\
$\begin{array}{l}\text { b. Predictors: (Constant), LN_UkuranPerusahaan, LN_K.Manajerial, LN_Profitabilitas, } \\
\text { LN_Likuiditas, LN_K.Institusional }\end{array}$
\end{tabular}

Besarnya nilai F tabel untuk df 1 (5) dan df 2 (108) adalah sebesar 2,30. Dengan demikian F hitung $(42,433)>F$ tabel 2,30 dan nilai signifikan $0,000<0,05$ maka Ha diterima yang berarti 
secara simultan semua variabel independen secara signifikan mempengaruhi kebijakan hutang perusahaan manufaktur yang terdaftar di Bursa Efek Indonesia tahun 2017-2019.

\section{Uji t}

Tabel 4.9. Uji t

\begin{tabular}{|l|l|r|r|}
\hline \multicolumn{3}{|c|}{ Coefficients $^{\text {a }}$} \\
\hline \multirow{5}{*}{1} & \multicolumn{1}{c|}{$\mathrm{t}$} & \multicolumn{1}{c|}{ Sig. } \\
\hline \multirow{4}{*}{1} & (Constant) &, 518 &, 606 \\
\cline { 2 - 4 } & LN_K.Manajerial & $-1,678$ &, 096 \\
\cline { 2 - 4 } & LN_K.Institusional &,- 709 &, 480 \\
\cline { 2 - 4 } & LN_Profitabilitas &,- 434 &, 665 \\
\cline { 2 - 4 } & LN_Likuiditas & $-13,633$ &, 000 \\
\cline { 2 - 4 } & LN_UkuranPerusahaan &, 505 &, 615 \\
\hline \multicolumn{2}{|l|}{ a. Dependent Variable: LN_KebijakanHutang } \\
\hline \multicolumn{2}{|l|}{} \\
\hline
\end{tabular}

Besarnya t tabel pada probabilita 0,05 dengan tingkat uji signifikansi 2 arah dan df 108 adalah 1,98217. Maka hasil uji t pada penelitian ini dapat dijelaskan satu persatu sebagai berikut :

1. Nilai $-\mathrm{t}_{\text {hitung }}-1,678>-\mathrm{t}_{\text {tabel }}-1,98217$ dan nilai signifikan $0,096>0,05$ maka berartiH0 diterima artinya saham yang dimiliki manajerial tidak mempengaruhi kebijakan hutang perusahaan manufaktur yang terdaftar di Bursa Efek Indonesia tahun 2017 - 2019.

2. Nilai - $\mathrm{t}_{\text {hitung }}-0,709>-\mathrm{t}_{\text {tabel }}-1,98217$ dan nilai signifikan $0,480>0,05$ maka H0 diterima yang berartisaham yang dimiliki institusional tidak mempengaruhikebijakan hutang perusahaan manufaktur yang terdaftar di Bursa Efek Indonesia tahun 2017 - 2019.

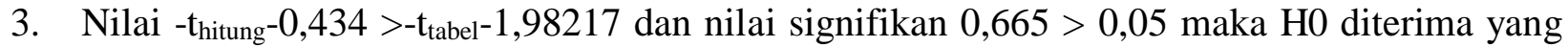
berartiprofitabilitas tidak ada pengaruhnyapadakebijakan hutang perusahaan manufaktur yang terdaftar di Bursa Efek Indonesia tahun 2017 - 2019.

4. Nilai -thitung -13,633 < -ttabel -1,98217 dan nilai signifikan 0,000<0,05 maka Ha diterima yang berarti likuiditas berpengaruh signifikan terhadap kebijakan hutang perusahaan manufaktur yang terdaftar di Bursa Efek Indonesia tahun 2017 - 2019.

5. Nilai thitung $0,505<$ ttabel 1,98217 dan nilai signifikan $0,615>0,05$ maka $\mathrm{H} 0$ diterima yang berarti ukuran perusahaan tidak ada pengaruhnya pada kebijakan hutang perusahaan manufaktur yang terdaftar di Bursa Efek Indonesia tahun 2017 - 2019.

\section{HASIL DAN PEMBAHASAN}

\subsection{Kepemilikan Manajerial dan DER.}

Hasil penelitian menunjukkan jika tidak terdapat pengaruh kepemilikan manajerial pada kebijakan hutang perusahaan manufaktur yang terdaftar di Bursa Efek Indonesia tahun 2017 2019. Hasil penelian ini juga sejalan dengan Lestari, Andini dan Abrar (2019) yang juga membuktikan jika kepemilikan manajerial tidak mempengaruhi kebijakan hutang perusahaan.

\subsection{Kepemilikan Institusional dan DER}

Hasil penelitian menunjukkan jika tidak terdapat pengaruh kepemilikan institusional pada kebijakan hutang perusahaan manufaktur yang terdaftar di Bursa Efek Indonesia tahun 2017 - 
2019. Hasil penelian ini juga sejalan dengan hasil penelitian Nurwani dan Christiana (2018) yaitu kepemilikan institusional tidak mempengaruhi kebijakan hutang.

\subsection{Profitabilitas terhadap DER.}

Hasil penelitian menunjukkan profitabilitas/ROA tidak mempengaruhi kebijakan hutang perusahaan manufaktur yang terdaftar di Bursa Efek Indonesia tahun 2017 - 2019. Hasil penelian ini sesuai dengan hasil penelitian Pradhana, Taufik dan Anggraini (2014) yaitu profitabilitas tidak berpengaruh terhadap kebijakan hutang.

\subsection{Likuiditas dan DER.}

Hasil penelitian menunjukkan hanya likuiditas yang memiliki pengaruh terhadap kebijakan hutang perusahaan manufaktur yang terdaftar di Bursa Efek Indonesia tahun 2017 - 2019. Hasil penelitian ini juga sejalan dengan penelitian Estuti, Fauziyanti dan Hendrayanti (2019) yang juga membuktikan ada pengaruh likuiditas secara negatif terhadap kebijakan hutang.

\subsection{Ukuran Perusahaan dan DER.}

Hasil penelitian menemukan tidak ada pengaruh ukuran besar kecilnya perusahaan terhadap kebijakan hutang perusahaan manufakturyang terdaftar di Bursa Efek Indonesia tahun 2017 - 2019. Hasil ini sejalan dengan penelitian Suryani dan Khafid (2015) yang menunjukkan ukuran perusahaan juga tidak berpengaruh terhadap kebijakan hutang.

\section{KESIMPULAN DAN SARAN Kesimpulan}

Kesimpulan dari hasil uji data yaitu secara parsial, Kepemilikan manajerial, kepemilikan institusional, profitabilitas dan ukuran perusahaan tidak berpengaruh terhadap kebijakan hutang perusahaan manufakturyang terdaftar di Bursa Efek Indonesia tahun 2017 - 2019 sedangkan likuiditas berdampak secara parsial pada kebijakan hutang perusahaan manufakturyang terdaftar di Bursa Efek Indonesia tahun 2017 - 2019. Secara simultan kepemilikan manajerial, kepemilikan institusional, profitabilitas, likuiditas dan ukuran perusahaan berpengaruh terhadap kebijakan hutang perusahaan manufakturyang terdaftar di Bursa Efek Indonesia tahun 2017 - 2019 dengan besarnya nilai Adjusted $r$ Square sebesar $64,7 \%$ dari variasi kebijakan hutang yang dapat dijelaskan oleh variabel 5 independen sisanya sebesar 35,3\% dijelaskan oleh variabel lainnya misalnya risiko bisnis, free cash flow, struktur aktiva dan lainnya

\section{Saran}

Saran yang dapat diberikan yang dapat bermanfaat adalah sebagai berikut:

1. Bagi akademik yang akan melakukan penelitian serupa sebaiknya mengganti variabel yang tidak terbukti pengaruhnya pada kebijakan hutang dengan variabel bebas lainnya yang mempengaruhi kebijakan hutang.

2. Bagi investor, yang ingin melakukan investasi pada sektor ini sebaiknya memperhatikan perusahaan yang memiliki tingkat hutangnya lebih besar dari modalnya.

3. Bagi perusahaan manufaktur, diharapkan agar lebih hati-hati dalam menggunakan hutangnya dimana pada sektor ini tingginya penggunaan hutang menyebabkan terdapat sebagian besar 
perusahaan manufaktur yang mengalami kerugian karena tidak dapat beroperasi dengan baik dengan tingkat hutang yang sudah terlampau tinggi.

\section{DAFTAR PUSTAKA}

Darmayanti, Fella Eka, dkk. 2018. Pengaruh Kepemilikan Manajerial, Kepemilikan Institusional dan Kebijakan Hutang terhadap Nilai Perusahaan (Studi Pada Perusahaan Manufaktur yang Terdaftar di Bursa Efek Indonesia Periode 2011-2015). Jurnal Manajemen dan Bisnis. Vol. XI. No. 1. e-ISSN : 2541-1047.

Kamaludin \& Rini Indirani. 2012. Manajemen Keuangan, Konsep Dasar dan Penerapannya. Edisi revisi. Bandung : CV. Mandar Maju.

Kasmir. 2015. Analisis Laporan Keuangan. Cetakan ke Lima Jakarta: Penerbit PT. RajaGrafindo Persada.

Lestari, Indah Puji, dkk. 2019. Pengaruh Kepemilikan Institusional, Kepemilikan Manajerial dan Kebijakan Dividen terhadap kebijakan Hutang dengan Free Cash Flow sebagai Variabel Moderating (Studi Empiris pada Perusahaan Manufaktur yang Terdaftar di Bursa Efek Indonesia Periode Tahun 2010-2016). Jurnal Ilmiah Mahasiswa S1 Auntansi Universitas Pandanaran. Vol. 5 No. 5. ISSN: 2502-7697.

Mulyawan, Setia. 2015. Manajemen Keuangan. Bandung: CV. Pustaka Setia.

Murhadi, Werner R. 2015. Analisis Laporan Keuangan : Proyeksi dan Valuasi Saham. Jakarta: Penerbit Salemba Empat.

Rodoni, Ahmad dan Herni Ali. Manajemen Keuangan Modern. Jakarta: Mitra Wacana Media, 2014.

Sinaga, Poltak. 2014. Manajemen Keuangan Teori dan Aplikasi. Medan: CV. Mitra.

Sitanggang, J.P. 2013. Manajemen Keuangan Perusahaan Lanjutan. Jakarta: Mitra Wacana Media. Subagyo, dkk. 2017. Akuntansi Manajemen Berbasis Desain. Yogyakarta: Gadjah Mada University Press.

Sudana, I Made. 2011. Manajemen Keuangan Perusahaan: Teori \& Praktik. Jakarta: Penerbit Erlangga.

Sumarsan, Thomas. 2013. Sistem Pengendalian Manajemen. Jakarta: PT. Indeks.

Sunyoto, Danang. 2013. Metode Penelitian Akuntansi. Bandung: PT. Refika Aditama.

Sunyoto, Danang. 2018. Dasar-Dasar Manajemen Keuangan Perusahaan. Cetakan Pertama. Yogyakarta: CAPS.

Tjeleni, Indra E. 2013. Kepemilikan Manajerial dan Institusional Pengaruhnya Terhadap kebijakan Hutang Pada Perusahaan Manufaktur di Bursa Efek Indonesia. Jurnal EMBA. Vol. 1 No. 3. ISSN : 2303-1174.

Abdullah, S.N., Yusof, M. and Nor, M. 2010. "Financial Restatements and Coporate Governance Among Malaysian Listed Companies". Manajerial Auditing Journal, Vol. 25, No. 6, pp. 526-552. Emerald Group Publishing Limited.

Martono,SU \& Harjito DA 2005. „Manajemen keuangan’. Penerbit: Ekonisia. Yogyakarta.

Wahidahwati, 2002. Pengaruh Kepemilikan Manajerial dan Kepemilikan Institusional pada Kebijakan Hutang Perusahaan: Sebuah Perspektif Theory Agency. Jurnal Riset Akuntansi Indonesia. 5 (1). 41-55. 
Pengaruh Faktor Fundamental pada Nilai Perusahaan sector Telekomunikasi di Bursa Efek Indonesia" . E-Jurnal Akuntansi Universitas Udayana. Vol,8. No.3, hlm. 386-393.

Ruan, W, Gary, T \& Shinguang, M 2011. Managerial Ownership, Capital Structure and Firm Value: Evidence from China" s Civilian-run Firms, Australasian Accounting, Business and Finance Journal. Volume 5.

Wahidahwati, 2002. Pengaruh Kepemilikan Manajerial dan Kepemilikan Institusional pada Kebijakan Hutang Perusahaan: Sebuah Perspektif Theory Agency. Jurnal Riset Akuntansi Indonesia. 5 (1). 41-55. 